\title{
Alumni Tracking of Guidance and Counselling Study Program State University of Medan
}

\author{
$1^{\text {st }}$ Mirza Irawan ${ }^{1}, 2^{\text {nd }}$ Ibrahim Gultom ${ }^{2}, 3^{\text {rd }}$ Zuraida Lubis $^{3}, 4^{\text {th }}$ Nur' Arjani $^{4}$ \\ $\left\{\left\{\right.\right.$ konsmirza@unimed.ac.id ${ }^{1}$, ibgultom@unimed.ac.id ${ }^{2}$, zuraidalubis@ unimed.ac.id ${ }^{3}$, \\ nurarjani@unimed.ac.id $\left.{ }^{4}\right\}$ \\ Universitas Negeri Medan, Jl. Willem Iskandar Pasar V, Medan ${ }^{1,2,3,4}$
}

\begin{abstract}
This study aims to obtain information from undergraduate alumni (S-1) of the Guidance and Counselling Study Program, Faculty of Education, Universitas Negeri Medan that relates to: 1) Alumni profile, (2) Alumni employability, (3) Alumni satisfaction, (4) Alumni current position and roles, (5) Alumni performance quality, (6) Stakeholders perception, and (7) communication between alumni and their almamater. The method used in this study was descriptive with a quantitative approach. Data were collected using a survey method with a questionnaire as a data collection tool. The results of this study are expected to be useful as a basic consideration in formulating policies to improve quality of administrative and academic services in the Guidance and Counselling Undergraduate Program, Faculty of Education, Universitas Negeri Medan.
\end{abstract}

Keywords: Alumni, tracking, guidance and counselling.

\section{Introduction}

The results of the Self-Evaluation analysis revealed that the curriculum at the Department of Guidance and Counseling Study Program, Faculty of Education, State University of Medan (PS BK FIP UNIMED) did not yet link and match the needs of stakeholders. This is due to, among other things, curriculum development has not been based on a holistic evaluation and the lack of lecturers' ability to translate the curriculum into learning activities. Based on the results of the Self-Evaluation, it was found that there was a discrepancy between academic achievement (high GPA) and the performance of graduates in the field.

Alumni are products of an educational institution. The quality of alumni shows the quality of the educational institution. To find out the quality of graduates produced, it is not enough just to look at the output, for example from the ability to master knowledge, skills and formal attitudes which are embodied in the Achievement Index. But it must also be detected from the outcome, namely how much graduates can be absorbed in the world of work. The relevance (suitability) of graduate education is shown through job profiles (types and places of work), job relevance with educational background, benefits of courses programmed in employment, graduate suggestions for improving graduate competencies. The success of university graduates (PT) in entering the world of work is one indicator of learning outcomes and the relevance of PT for the community. Thus, universities are responsible not only for equipping graduates with certain competencies (learning outputs) but also for facilitating and bridging graduates to enter the workforce. In addition, the relevance of education is also shown through the opinions of graduate users regarding graduate user satisfaction, graduate competencies and 
graduate suggestions for improving graduate competencies. How much higher education graduates are able to take part in development according to the relevance of their education can be traced to the graduates (Tracer Study).

PS BK FIP UNIMED has an important position in developing human resources. One of the benchmarks for the success of PS BK FIP UNIMED is to produce quality graduates who have competencies according to their fields of knowledge so that they can provide benefits in work and have competitiveness. In terms of employment, the benefits of PS BK FIP UNIMED graduates are the ability to apply aspects of counseling services in increasing knowledge, skills and attitudes. The impact of graduate competence on work is getting promotions, salary increases, getting awards for achievements and obtaining work support facilities. From the aspect of performance quality, PS BK FIP UNIMED graduates are expected to improve selfdevelopment skills (advanced studies), leadership skills and teaching abilities. So that in the end the performance of PS BK FIP UNIMED graduates has innovative behavior, responsibility, achievement in work

Alumni tracing (Tracer Study) can measure and track the performance of graduates so that clear indicators can be obtained about the profile of graduates. Schomburg [1] states that tracer studies have been used as one of the requirements for university accreditation. Tracer study is becoming increasingly important because it can provide various important information for higher education development, acts as a tool to evaluate the relevance between higher education and the world of work, can provide useful input for lecturers and administrators to improve performance. Based on the description of the background above, the Research Team will conduct research on Alumni Tracing (Tracer Study) of the Undergraduate Study Program (S-1) Guidance and Counseling, Faculty of Education, State University of Medan.

\section{Methods}

The method used in this research is descriptive to obtain an overview of graduates, superiors and colleagues. To obtain research data, the Census method was used by using a questionnaire as a data collection tool. Graduate respondents in this study were all graduates of PS BK FIP UNIMED in 2000 - 2013. The instrument of this research is the alumni tracking questionnaire (Tracer Study) which was developed by the Research Team based on theoretical studies and needs analysis.

Table 1. Instrument grid.

\begin{tabular}{cll} 
No. & \multicolumn{1}{c}{ Variabels } & \multicolumn{2}{c}{ Indicator } \\
\hline 1. & Graduate satisfaction & - Substance in the field of \\
& & science/curriculum \\
& & Service \\
& & - Benefits of learning experience \\
& & in PS BK \\
\hline 2.2 & Distribution of Graduates & - Region \\
& & - Employment \\
\hline 3.3 & Competitiveness & - apply for a job \\
& & - continue studies \\
& & - promotion \\
\hline 4. & Quality of graduate & - Achievement \\
& performance & - Award \\
\hline 5. & Position and role of & - Before graduation \\
\hline
\end{tabular}




\begin{tabular}{lll}
\hline & graduates & - After graduate \\
& & - Role in society \\
\hline 6. & Communication between & - IKA membership \\
& alumni and alumni-alma & - Communication media \\
& mater & - Activity type \\
\hline
\end{tabular}

The data collection technique used is the census. The census was conducted by distributing questionnaires to all graduates of PS BK FIP UNIMED, graduate supervisors, and graduate colleagues. The survey results were collected by filling out online questionnaires by the respondents. In collecting data, the research team will develop a website-based instrument application

The collected data was then tabulated and statistically analyzed using Microsoft Office Excel. Because the online questionnaire that was made did not limit respondents to filling out all the questions, there were questions that were not answered. There are also questionnaires that are not actually the target respondents. Therefore, the data analyzed are all incoming and valid data only (data from non-respondent fillers are not processed). The results of the analysis are presented in the form of a report containing statistical information which is then packaged descriptively.

\section{Result and Discussion}

There were 52 graduates of the BK FIP UNIMED Study Program who became the research target. Overview of graduates of the BK FIP UNIMED Study Program that have been surveyed include graduate profiles, learning experience, status of further study after graduation, field of work, quality of performance, competitiveness of graduates in the field of work, competency improvement before and after graduation, graduate satisfaction, hope of restudy, the need for graduates for further study, orientation on job satisfaction, the role of study in life and a forum for alumni associations.

The total of graduate respondents who answered the questionnaire and could be analyzed were 52 respondents. Judging from the gender of the respondents who participated in this study $76.9 \%$ were female and $29.1 \%$ were male.

Table 2. Gender of respondents.

\begin{tabular}{ccc} 
No. & Gender & Total $(\%)$ \\
\hline 1 & Male & 29,1 \\
\hline 2 & Female & 76,9 \\
\hline
\end{tabular}

Then from the first registration year, respondents registered from 1981 to 2016. Most of the respondents started the first registration in 2013 as many as 6 people (3.12\%), followed by 2016 as many as 5 people (2.6\%), and in 2009 as many as 4 people (2.08\%), in 2003 as many as 3 people. Then it spreads every year the batch of 1 to 2 people.

Table 3. Distribution of respondents' registration years.

\begin{tabular}{lccc} 
No. & Year of Registration & Number of Respondents & Percentage \\
\hline 1 & 2013 & 6 & 3,12 \\
\hline
\end{tabular}




\begin{tabular}{lllc}
\hline 2 & 2016 & 5 & 2,6 \\
\hline 3 & 2009 & 4 & 2,08 \\
\hline 4 & 2003 & 3 & 1,56 \\
\hline
\end{tabular}

The success of the UNIMED BK Study Program in implementing the learning process has an impact on graduate satisfaction. Graduate satisfaction can be identified from satisfaction with the substance of the field of science and the usefulness of courses, administrative and academic services, as well as the benefits and learning experiences obtained from the Unimed BK Study Program. Satisfaction with the substance of the field of science and the usefulness of the course in terms of the suitability of the substance of the subject with the current field of work as many as 36 people (69.2\%) stated that the substance of the course with the current field of work was very suitable, 15 people $(28.8 \%)$ said it was suitable, 1 person stated that it was not suitable. Satisfaction with the substance of the field of science and the usefulness of the course in terms of the usefulness of the course in the field of work can now be explained as many as 35 people $(67.3 \%)$ stated that it was very useful, 16 people (30.8\%) said it was quite useful, and 1 person $(1,9 \%)$ stated less useful.

According to 29 people $(55.8 \%)$ very good, 21 people $(40.4 \%)$ good, 1 person $(1.9 \%)$ less, and 1 person (1.9\%) ) very less. Then specifically in terms of several aspects can be seen in the following table.

Table 4. Graduates' satisfaction with administrative/academic services.

\begin{tabular}{llcccl}
\multirow{2}{*}{ No. } & & \multicolumn{4}{c}{ Classification $(\%)$} \\
\cline { 3 - 6 } & & $(4)$ & $(3)$ & $(2)$ & $(1)$ \\
\hline 1 & Graduation & 61,5 & 34,6 & 3,8 & \\
\hline 2 & Public relations & 51,9 & 42,3 & 5,8 & \\
\hline 3 & Exam & 51,9 & 46,2 & 1,9 & \\
\hline 4 & Case Resolution & 50 & 46,2 & 3,8 & \\
\hline 5 & Employee Professionalism & 50 & 44,2 & 5,8 & \\
\hline 6 & Book Reference & 38,5 & 51,9 & 9,6 & \\
\hline 7 & Academic Guidance & 53,8 & 44,2 & & 1,9 \\
\hline 8 & Thesis Guidance & 71,2 & 28,8 & & \\
\hline 9 & Quality of learning in class & 46,2 & 51,9 & 1,9 & \\
\hline 10 & Practical Activities & 61,5 & 36,5 & & 1,9 \\
\hline
\end{tabular}

The knowledge gained during study at the BK UNIMED Study Program will have an impact on improving the quality of graduates. Qualified graduates will be able to answer the challenges of competition with graduates from other universities. The ability of the UNIMED BK Study Program to access the work environment will make it easier to get information, selection opportunities and be selected and excel in the work environment. Specifically, the competitiveness of graduates can be seen in the following table.

Table 5. Competitiveness of graduates.

\begin{tabular}{lllcccc}
\multirow{2}{*}{ No. } & \multicolumn{2}{c}{ Indicators } & \multicolumn{3}{c}{ Classification (\%) } \\
\cline { 3 - 5 } & \multicolumn{2}{l}{ Gaining Access to Information } & $(4)$ & $(3)$ & $(2)$ & $(1)$ \\
\hline 1 & Selection $/$ Job Application & 75 & 32,7 & \\
\hline 2 & S & & 19,2 & 5,8 & \\
\hline
\end{tabular}




\begin{tabular}{|c|c|c|c|c|}
\hline & Opportunities & & & \\
\hline 3 & Opportunity to be Chosen/accepted & 69,2 & 28,8 & 1,9 \\
\hline 4 & Opportunity for further study & 98,1 & & 1,9 \\
\hline 5 & Job Promotion & 75 & & 25 \\
\hline
\end{tabular}

The quality of the performance of the graduates of the BK UNIMED Study Program will affect their attitudes and abilities in self-development and leadership. Several things that are measured related to self-development ability are innovative behavior, responsibility, contribution to the institution, and awards and achievements. The following is the quality of graduate performance in terms of innovative behavior, responsibility, contribution to the institution, and awards and achievements.

Table 6. Quality of graduate performance

\begin{tabular}{llcccc}
\multirow{2}{*}{ No. } & Indicators & \multicolumn{3}{c}{ Classification (\%) } \\
\cline { 3 - 5 } & & $(4)$ & $(3)$ & $(2)$ & $(1)$ \\
\hline 1 & Innovative Behavior & 38,5 & 55,8 & 5,8 \\
\hline 2 & Responsibility & 48,1 & 50 & 1,9 \\
\hline 3 & Contribution & 46,2 & 51,9 & 1,9 \\
\hline 4 & Awards and Achievements & 19,2 & & 80,8 \\
\hline
\end{tabular}

The research carried out cannot be separated from limitations, according to the author, it is necessary to have good communication between researchers, majors and alumni in determining the material/content and technical data collection. The tracer study findings show that aspects of academic services that still need to be improved are library services and academic guidance. Academic administration services that still need to be improved are case management, employee professionalism and the availability of teaching materials.

The competence of graduates who are not yet optimal which can provide input for curriculum improvement is how competence in mastering science and knowledge can meet the needs in the field of work. Among graduates of the Unimed BK Study Program, the desire to form social networks among alumni still needs to be improved so that communication between alumni is well established. Increasing the activities of the Unimed BK Study Program Alumni Association so that it can accommodate alumni widely by offering interesting programs so that the need for graduates to always be involved in improving the performance of the study program can be increased. Suggestions for opening a further study program (S2) Guidance and Counseling. This suggestion is also to accommodate the wishes of the majority of graduates $(98.1 \%)$ who still choose Unimed to continue their studies.

\section{Conclusion}

Based on the results of the research and discussion, it can be concluded as alumni respondent profile: the number of respondents is 52 people, in terms of gender $23.1 \%$ male and $76.9 \%$ female. The registration year of alumni respondents spread from 1981 to 2016. With the majority of the study duration was 3.5 to 4 years as much as $71.2 \%$. The Grade Point Average (GPA) is generally 2.76 to 3.50 as much as $59.6 \%$. The waiting time to get a job is the majority of respondents in the range of less than 3 months as much as $55.8 \%$. Status 
Institutions where respondents work $76.9 \%$ are in government/state agencies/agencies and $23.1 \%$ are private/non-state institutions/agencies. Judging from the type of work, almost all respondents work as guidance and counseling teachers as much as $96.2 \%$. Alumni satisfaction with the substance of the field of knowledge obtained from the BK Study Program is generally in the very appropriate range, for administrative and academic services, as well as benefits and learning experiences in the very appropriate range. The competitiveness of alumni with other universities is generally in the very good range, as many as $98.1 \%$ of alumni are willing to continue their studies at Medan State University. The quality of graduate performance in general is in the very good category. As many as $85.7 \%$ of alumni have received achievements/awards in categories 1 to 3 times:

\section{References}

[1] Schomburg H. Handbook for Graduate Tracer Studies: Centre for Research on Higher Education and Work, University of Kassel, Germany; 2003. 